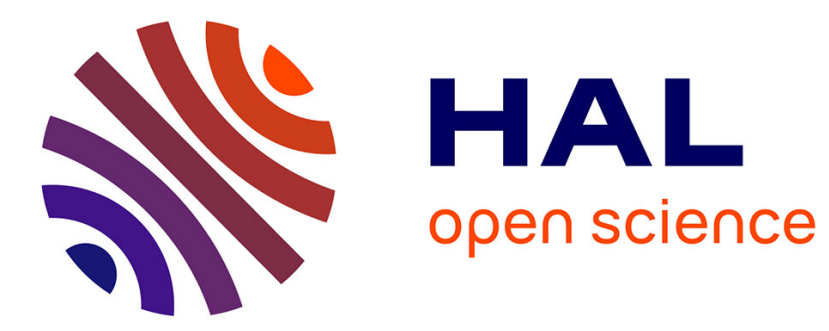

\title{
Orchestrating innovation with user communities in the creative industries
}

G. Parmentier, Vincent Mangematin

\section{To cite this version:}

G. Parmentier, Vincent Mangematin. Orchestrating innovation with user communities in the creative industries. Technological Forecasting and Social Change, 2014, 83 (1), pp.40-53. 10.1016/j.techfore.2013.03.007 . halshs-00848861

\section{HAL Id: halshs-00848861 https://shs.hal.science/halshs-00848861}

Submitted on 27 Sep 2013

HAL is a multi-disciplinary open access archive for the deposit and dissemination of scientific research documents, whether they are published or not. The documents may come from teaching and research institutions in France or abroad, or from public or private research centers.
L'archive ouverte pluridisciplinaire HAL, est destinée au dépôt et à la diffusion de documents scientifiques de niveau recherche, publiés ou non, émanant des établissements d'enseignement et de recherche français ou étrangers, des laboratoires publics ou privés. 


\title{
ORCHESTRATING INNOVATION WITH USER COMMUNITIES IN THE CREATIVE INDUSTRIES
}

\author{
Guy Parmentier \\ University of Grenoble Alpes / CERAG \\ Grenoble \\ guy.parmentier@iae-grenoble.eu \\ and \\ Vincent Mangematin \\ Grenoble Ecole de Management \\ Grenoble \\ vincent.mangematin@grenoble-em.com
}




\title{
ORCHESTRATING INNOVATION WITH USER COMMUNITIES IN THE CREATIVE INDUSTRIES ${ }_{1}$
}

\begin{abstract}
The digital creative industries exemplify innovation processes in whichuser communities are highly involved in product and service development, bringing new ideas, and developing tools for newproduct uses and environments. We explore the role of user communities in suchco-innovation processes via four case studies of interrelations between firms and their communities. The digitization and virtualization of firm/community interactions are changing how boundaries are defined and how co-innovation is managed. The transformation of innovation management is characterized by three elements: opening and redefining firm boundaries; opening of products and services to community input and reducing property rights; and reshaping organization and product identities. Innovation in collaboration with user communities requires firms to orchestrate their communitiesand theirinterrelationships toencouragethe creativity and motivation of users, and develop the community's innovatory capacity.
\end{abstract}

Keywords: online communities, user, innovation, videogame, community management, coinnovation.

1 The authors would like to thank the participants of the OI seminar series at Grenoble Ecole de Management, the anonymous reviewers and Dr Elke Schuessler as editor of the special issue for their helpful comments on the different versions of the paper. Usual caveats apply. 


\section{INTRODUCTION}

The digital creative industries exemplify innovation processes where users bring new ideas, develop tools to play, create new game environments, and to innovatedirectly. The digital creative industries are creative industries based on digital content. Thesescreative firms engage with user communities [1]- whether amateurs or hardcore video gamers -to promote new scenarios, games or ways of using existing devices[2], and the two converge to share in developing new products, even if they value them for different reasons (users for the pleasure of playing and the chance of using their individual creativity to improve the product, firms for the chance such innovations offer for increased turnover and profits). It is common to say that gamers can simultaneously be both users and developers, but what is new is that theblurring of firm frontiers in digitized industries allows for fluid interactions between user communities and firms[3, 4].

Users participate in online user communities, which support and stimulate the diffusion of on-line products. The digitization of content and virtualization of interactions between firms and their user communities changes the definition of boundaries between the two, and may even modify their respective identities. Firms not only interact with individual users, they also have relationships with organized communities[5]. The goals, valuesand organizationof firms anduser communities differ, eventhoughthey collaborate actively in creatingnew products and services, and, to manage innovations, firms orchestrate their relationships with online usercommunities who co-develop innovations and thus achieve ongoing product transformation[6].Lead user approach [7] mostly reports interactions between the organization and individuals. Digitalization and the subsequent virtualization of interactions change the nature of the relation. Users are forming communities, leading to a new model of innovation: and the online user community innovation model emphasizes the central role of community which blurs the boundaries of organization, and requires additional 
understanding of what communities are, how they work and how they interact with firms.

Based on four case studies to maximize the variety of contexts we examine - two original case studies (Trackmania and Freebox), for which we collect and analyze data, and two indirect case studies based on secondary data (Propellerhead and MySQL) - we explore the interrelations between firms and their online user communities to co-innovate on-going product development. We examine the activities of three communities which are closely related to the firms involved and one that is independent - in each case, we study interactions between communities and firms, and the ways in which creativity and innovations are stimulated or restrained. The paper characterizes the co-innovation process with user communities.

The next section introduces the theoretical background, highlighting gaps inthe knowledge about user communities in the digitized creative industries, and considersthe need to manage interactions between firms and on-line user communities at the micro (i.e. firm) level. We then discuss our methodology, outline the cases and provide a detailed representation of our findings, before discussing the results in the light of existing theory and drawing implications for management practice and for the digital creative industries. The paper contributes to existing theory in three ways: first digitization of firms' interactions withonline communities increases fluidity of their interactions and allows co-innovation process $[3,4,8]$; second it underlines the blurring of the boundary between existing and ongoing product, since the community of users contributes to changing the product on a continuous basis (Web 2.0 spirit). Third, it emphasizes the blurringof boundaries between firm and communities. As digitization progresses, user communitiesbecome the new loci of innovation in the creative industries, blurring the boundaries between firms and their communities, as well as the differentiation between production and post-production. Users are involved in developing products which are only stable only for short periods. The 
identities of user community and firm become merged in 'product communities', shared by both parties. Orchestrating their user communities becomes a central firm concern,as the continuum between creation, production and post-production allows communities and firm to retaintheir own identity but at the same time to collaboratein the on-going development of the usage and utility of products.

\section{BACKGROUND AND KNOWLEDGE GAPS}

Since von Hippel's seminal work[9], the 'lead user' approach has been seen as the major avenue via which firms involve users or their representatives in their product or service development processes. These are userswith advanced requirements who involve themselves with the firm to satisfy those requirements - but the development effort remains essentially located within the firm. The collaboration of on-line communities with digital creative industriesexemplifiesa new model where users are directly involved in the co-development of products, blurring the frontiers of the firm and the identities of users and developers.

\subsection{Innovation with digital on line communities}

The lead user approach developed by von Hippel describes how firms source new knowledge from users who have themselves experimented intensively with the product and who are expecting benefits from the improvements to which they contribute. Although it underlines the role of distributed knowledge in the innovation process, the lead user approachmaintains a clear distinction between users and firms. In concrete terms, the company identifies lead users and invites them to participate in workshops within the company in order to help design new products $[10,11]$ - but while lead users bring new ideas and knowledge, the company remains the undisputed owner of any resultant new product concepts: the innovation process remains internal, the boundaries are clearly defined and the firm orchestrates its relationships with individual lead users[6]. 
Mahr and Lievens[12] examine the creation of innovation by lead users in virtual communities, describing their traits and analyzing how suchfeatures contribute to the innovation process. They find that lead users in virtual communities tend to propose solutionfocused contributions which provide greater value to the firms thanproblem-focused solutions, and have valuable expertise along design and usability dimensions. Lead users in virtual communities are more likely than regular lead users to make contributions on their own initiative, and more likely to codify their contributions, so providing the firm with more valuable innovations. Pitta and Fowler emphasize the role of communities of interests, and identify community leaders, those who are highly involved in such forums[13], and findthat they can play a key role as coordinators ofsuch communities.Burger-Helmchen and Cohendet[2] extend this approach from lead users to online communities: focusing on the game industry, they produce a categorization of user communities: developers, testers, hardcore players and average users. The communities of users who interact with different firms and communities to produce new video games tend to involve the first three first types. Dahlander and Magnusson[1] define "harnessing a community" as "accessing a community to extend[a firm's] knowledge base, aligning [its] strategy with that of the community and assimilating the work developed within the community in order to integrate and share results". Burger-Helmchen and Cohendet analyze the practical interactions between firms and communities, emphasizing the alignment of interests between the two. On-line communities, with theirlack of structural mechanisms, open generative spaces in which new organizational mechanisms of collaboration can be explored and replace traditional ones tofacilitate knowledge collaboration and enable the unconstrained recombination of knowledge. Faraj, Jarvenpaa and Majchrzak[3] characterize on-line communities as fluid entities, where boundaries, norms, participants, artifacts, interactions and foci continually change over time, and it is this central characteristic that enables new knowledge collaborations, as it leads to 
novel alignments and allows for the reciprocal assimilation of knowledge by both firms and communities.

Faraj etal. emphasize the ways in which on-line communities can lead to dynamic changes. By introducing interactionsin the community, by shortening reaction times, by discussing a wide variety of ideas, online communities generate responses that are valuable to firms' product development efforts, and the fluidity of community operations can dynamically change boundaries between firms and community members, transformingusers'rolesand their levels of involvementin new product development processes.

While the lead user approach maintains the boundaries between communities and firms, with lead users being invited into firms to participate in product development, the fluidity of on-line communities blurs those boundaries [8], and this boundary permeability can impact different dimensions: (1) appropriability, as community involvement in innovation - or perhaps pre-existent innovation within that community - may prevent the firm from full appropriating or patenting co-generated product concepts; (2) tools may be shared between the firm and the community (as is typicallythe case with open source software); (3) identitiesbecome blurred[4], and community members may come to have dual identities, as both gamers and developers for firms. When company boundaries become permeable, the question arises of the community's identity vis-à-vis that of the company. Organizational identity is an important element of both parties, since it answers the question "who are we?'[14], defining who is part of the group and who belongs to a different group. Identities in on-line communities cannot be defined by members' locations or roles as individuals are usuallyinvolved in different communities simultaneously $[4,15,16]$. To what extent do such communities remain independent from the firms? The literature identifiesdifferent situations where usercommunities are independent from the companies, while other authors report 
common boundaries: firms can originate and host communities [17] - or can even originate from user communities, as for example MySQL [1].

The notion of a user community as a new locus of innovation represents a radicallydifferent organizational structure from the lead user approach, where the firm controls the innovation process, even if it builds on user/lead users ideas. When innovation originates from within the community, the firm acts as a specific member of the community and is just part of the innovation process, co-innovating with users to propose ideas, prototypes and products which fit their needs.Appreciating this structural difference is crucial for better understanding how such communities work.

\subsection{Building on online user communities}

In the online user communitymodel, the boundaries, roles and identities of firmsbecome blurred - and the same individuals may be both firm employees and belong to (perhaps several) user communities, playing different roles in each setting [2]. How the community functionsaffectsthe innovation process, and firms need to make sense of the fluid boundaries typically involved in this style of innovation process, allowing (and managing) convergence or divergence between user communities and firms, stimulating the pull effects of users on innovations and enabling the dynamic emergence of different roles as part of the interaction. User communities - whether on-line $[5,18,19]$ or off-line - such as those which help design new consumer goods in the sports sector [20-23]- are generally organized around three main pillars: individual objectives and motivations;community governance and leadership; and circulation of information and running recurring events.

\section{Individual Objectives and Motivations}

User communities are (generally) groups of individuals who share similar interests and need to interact to perform their activities(e.g., on-line gaming), and so value information 
exchange and sharing. Their members are generally highly motivated by the prospect of improvements in their focal product or service, and can provide firm developers with different contributions depending on whether their interests are orientated towards using the product or towards its technology [2].Jespersen and Frederiksen [17] found that users usually contribute from a 'hobbyist' standpoint, a perspective that positively affects their willingness to share their innovations. So they tend to reveal their ideas and innovations to firms' product platformsfreely,thus contributing to improving its position at no cost to the company, as resultantnew product features become available to all users via user-to-user sharing, or via product sales. They respond to 'firm recognition', which we can define as a motivating factor for them joining the firm's domain and exercising their creativity in innovating around its products. Raymond [19], Osterloh and Rota [24] and Lerner [25] all note that open source communities are often started whenusersdevelop new software by and for themselves. The chance to gain reputation, to exchange ideas and experiences with like-minded enthusiasts, and to signal to potential employers beyond the community for purposes of advancing their careers, are their main motivations for being involved in communities, whose social norms include a strong sense of commitment towards the community and its members [26]. Members are keen to gainhigh reputations in the eyes of their peers [5, 19, 25], or of the company [17], to build up their identities and so perhaps improve their career prospects [25].

Firms and users pursue different, non-aligned goals, firms seeking to improve their profitability and to generate turnover and benefits, while users seek the pleasure of using the product, ofexchanging and sharingideas, as well as of being involved in product innovation, with the chance of achieving recognition for their efforts. Developing innovation in partnershipwith a user community involves attracting users'attention and cultivating and motivating themwith relational systems adapted to each user category, and first and foremost, aiming at establishing relations with those who have the highest levelsof innovativeness and 
creativity and interest in and knowledge of the product(thus, effectively, lead-users).

\section{Governance and Leadership}

O’Mahony and Ferraro [27] examine how a social group designed a shared basis of authority and thus, a governance system, and detail how the system introduced formal authority and leadership into the community. Although technical proficiency is an important criterion for leadership in open source communities, skill in building the organization becomes increasingly important over time. User communities also exhibit 'coattailing'behaviors which align individual actions and collective activities for coordination and cooperation [28]. Assessing a large online community of software developers, Stewart [29] shows that community members tend to evaluate each other's reputations and status according to publicly available social references. Burger-Helmchen and Cohendet emphasize the different roles of users within their communities and how each role is enacted at any moment.Community governance mechanisms may be based on implicit or on more explicit hierarchies [30]. In many ways, although communityboundaries may remain fuzzy, community governance depends on similar mechanisms to those operating in firms. Community leaders play central roles, motivating members to participate, and become 'heroes'with whom community members identify: their roles are based more on animation than on hierarchical control:status and skill recognition are central. Where individual members are sponsored by companies, they are more likely to develop quality relationships with others and thusgain more important roles in their communities[31], so sponsoring the more active members of a community seems a good strategy for a firm seeking to harness that community's energyand make it a complementary asset.Butthe degree of alignment betweenfirm and community interests is also important - too much alignment increases similarities and can kill off the community's creativity, but complete decoupling will not support effective interactions. Two levels of alignment have to be managed: community 
members' alignment with the product or game, and the alignment of firm and community objectives.

\section{Information and Events}

Community leaders are central to the life of communities: they manage and animate them by setting new challenges and promoting information exchange, and usually play a wide variety of roles - as experts, animators, testers and as advisors. The circulation of information is a key element in how communities function, creatingand fosteringcommunity feeling, sharing news and technical information, and promotingthe status of community members. At the same time, the activities of searching for problems and developing new functionalities also have an important impact on the value of communities' contributionsto product development [12]. Organizing events is another important factor in keeping communities lively - for virtual communities these are usually on-line events, but some also run actual physical meetings, such as the Nadeo community's worldwide competition. These gatheringshelp structure the life of the community, giving members the opportunity to meet leaders personally and to be recognized as members, to validate their status and to meet and gain the recognition of fellow members. Such events (competitions, beta tests, evaluations, thematic events) enable heterogeneous users to become involved as early as possible in the community's innovation activities, encouraging the development and diffusion of innovation throughout the community [32]. Firms can channel participation through supporting community events, helping leaders to organize them, and so encourage innovation activities and community development. Such interactions help evolve and refinethe boundaries between firms and their communities. Virtual interactions reinforce participation in events and the development of ideas, and their heterogeneous membership means online communitiescan stimulate more 'out of the box' ideas and innovations than are likely to arise from within firms, where developers tend to be over-conscious of existing concepts and 
solutions.

The intensive use of internet and the introduction of Web 2.0 logics have profoundlychanged innovation models. The online user community innovation model emphasizes the central role of community, which blurs the boundaries of organization, and requires additional understanding of what communitiesare, how they work and how they interact with firms.

Table 1 sums up the characteristics of lead users and on-line user community models as loci of innovation. To study the management of innovation inuser communities, i.e. the articulation between firms and user communities to achieve innovation, and compare the mobilization of lead users and the co-development with user communities, we analyze the innovation processes in four firm/user community couples.We focus our attention on firm/community relations, creation and communication tools and community events that encourage members to contribute to the innovation process and to the vitality of the community, and also consider the question of how firms orchestrate their user communities' innovation efforts.

Insert Table 1 here

\section{METHODOLOGY}

\subsection{Research design}

The paper focuses on digital creative industries and aims to understand the interplay between online user communities and firms, to describe the user community innovation process and thus understand how firms manage, and benefit from, innovating in collaboratingwith user communities. We used a multiple case research design [33]to examine 
the interactions between firms and their user communities via four case studies: comparing two direct case studies (Trackmania and Freebox)with two that have been well documented in the literature(Propellerheadand $M y S Q L$ ). Our research focuses on two units of analysis: the innovation processes and the organization of firms and user communities. Case study selection was based on theoretical criteria - the ways in which firms established their connections with theiruser communities, and the size of those communities - and we selected cases addressing two distinct ways in which user communities are hosted by firms: in three cases, the communities were at least partially hosted by the firm and one was independent of the company. The relational mechanisms between the companies and the communities also took a variety of forms: forums and toolkits supplemented content creation in the Trackmaniacase; MySQLemployed forums and open source development tools;Propellerhead drew on a forum and partial toolkits;and Freeboxused forums, a setting and open-source software tools. Our four selected firmsoperated in differentactivity sectorsthree in software sectors (in video games, music and in databases) and one (Freebox) in the telecommunications sector: all provided support for user/creators to design new games, to create music or to disseminate creative products or updates. Table 2 characterizesoursample cases.

Insert Table 2 here

\subsection{Data collection}

Our data collection strategy focusedon tracking the co-creation activities between firms and user communities, which we defineas thosein which the userscontribute -directly or indirectly- to innovation processes: they may range from debate in a forum with users about idea of product improvement to direct product development by users. In the cases of 
TrackMania and Freebox, we carried out 24 semi-structured interviews with community entrepreneurs. For the former, we focused on the most active individuals in the general forum - managers of the most well-known sites, developers and the director of Nadeo: for the latter, we interviewed the developers and managers of the most recognized sites. We supplemented these interviews with documentary research on the community sites and in the specialist press. The data was collected over a period of three years with a historical restitution for the pre-data collection period. For case studies based on the literature, we used the research articles describing these cases, as a basis: threearticles and a thesis in the case of $M y S Q L[1,5$, 31] and two articles about Propellerhead[17, 34]. The richness of this case material allowed us to access information about the user/firm relationships, the mechanisms firms used to involve users in the innovation process, and they systems they used to manage that involvement. The management science literature provided a rich source of secondary data (such as Weick's article on the collapse of sensemaking in organizations based on an account of the 1949 Mann Gulch forest fire disaster [35]), and we supplemented this data from documentary research on blogs and websites (videos, interviews, articles), company websites and community forums. We used these data to write chronological cases histories for each firm which identified their co-creation activities with their communities.

\subsection{Analysis}

For TrackMania and Freebox, we used a coding method with a theoretical objective[36] to analyze data, supported by Altas.ti software, and triangulated all the facts and arguments identified during our data collection via analyses of the community forums. The theoretical objective coding method involved categorizing and interpreting the qualitative data, with the firstorder analysis categories based on our theoretical framework. We coded the linkages between firms and communities (forum activities, meetings inside and outside the firm), users' contributions to the innovation process (creation of content, of new 
functionality, of new tools and ideas, appearance of new uses, beta tests, bug descriptions, evolutions of product and services) and the life of community (creation of websites, events, leaders' appearances, clashes and disputes), and then compiled this information intochronologicalcase studiesfocusedon co-created innovative activities.Tables 3, 4 and 5 display what the different cases under review have in common and where they differ. All the cases follow the same innovation process framework, which is structured in three phases: design (identification of problem, idea generation, idea selection, development of new concepts), production (R\&D, development of product and service, creation of content), postproduction (product and service diffusion and further improvement). These phases are not always linearin creative industries: when a user creates content for a product diffused via theinternet, the product/service may be in post-production, but the user may continue to participate in its development by producing content for it. Next, we analyzedour chronological cases to find theoretical constructs, interactions andemerging patterns of relationships and activities within each case, and thensought to match those patterns across to other cases to develop more robust theoretical concepts. Finally, we looked for similarities and differences between the innovation processes in each case to discover which processes and activities facilitated innovation in user communities - these are reported at the bottom of each table. The following section illustrates the history of the four user communities and their members' involvement in innovation processes.

\section{THE CASE STUDIES}

\subsection{Trackmania}

Founded in 1999, Nadeo is a small video games producer which was acquired by the video games editor Ubisoft in 2009. Nadeo develops and edits the Trackmania on-line series 
of car races: the game includes a toolkit which enables players to create content - circuits, cars, video, mini web sites - as well as activities: races within a network, local forums and instant messages. By 2009, the Trackmania forums had registered 34,000 members who exchanged 450,000 messages, and its players had created more than 150,000 circuits in 3 years, launched dozens of competitions, and produced thousands of videos. Trackmania's sitedirectory lists over 400 sites for players, of which some - TM Exchange, Car Park and TM Ligues - have become very popular. Players group together in teams to participate in competitions, share out tasks between creators, managers and competitors to manage the race servers, create their own types of cars, and plan training sessions. Trackmania's CEO and his collaborators participate regularly in the user community's general forum, and the company supports the players' competitions and has encouraged a large new community web site financing its hosting, supplying technical support, and maintaining direct links with the managers of the community's most-visited sites. Nadeo has progressively reintegrated innovations originating from the community into its different published versions of the game, including automatic management of graphic resources, exchange of circuits, and access to players' mini sites. Observing the players' creations and behaviors has allowed Nadeo toencourage the game's evolution by including news about community and regional player rankings, and offering more diversified graphical worlds: so the community has now become an inseparable part of the company's identity. In 2009 Nadeo's web site brought the sites managed by the players to the forefront, and arranged for players to have direct access to the community's different forums. The players see Nadeo not just as a commercial enterprise but as an enthusiastic game creator, and the company reinforces this impression by regularly producing free 'add-ons' for games already on the market and distributing several complete versions of the games for free, and has continued these practices since being acquired by Ubisoft. 


\subsection{Freebox}

Iliad, founded in 2002, was the first broadband internet operator to market a triple play accesspackage ${ }^{2}$ based on the innovative Freebox modem, which can enable users to configure specific services, set their machines up in a network, produce original multimedia configurations, edit telesites ${ }^{3}$, and broadcast their videos on TVperso. The Freebox community is made up of about a hundred web sites directly managed by community members, via which they exchange technical information ideas and advice. As soon as operations started and communities emerged, Iliad established numerous connections with them, and its employees and directors made themselves available to chat with fans of the brand in community newsgroups. The operator (Free) systematically made contact with the managers of the most quickly developing sites, and Iliad now organizes regular meetings between its CEO and managers of the largest community sites. Iliad givesfinancial aid to Freenews (55,000 registered members, 600,000 forum messages in 2010) and hosts its servers for free, as well as those of the $\mathrm{ADUF}^{4}$ (74,000 members, 600,000 messages) and Freeplayer (40,000 members, 57,600 messages), and provides technical and administrative aid to UniversFreebox.com (12,000 registered members, 70,000 messages), a user association that attractsforeign television channels to become part of Freebox's TV package. The community also produces service ideas via its forum discussions or during regular meetings with the site managers, and has inspired some of the innovations that have been progressively integrated into successive Freebox versions: Wi-Fi, TNT tuner, multicast video, digital video recorder, TV perso and Freeplayer. As with Trackmania, the community's identity is part of the Freeboximage: the main user sites'names begin with the radical free (thus using it as a

\footnotetext{
${ }^{2}$ The package combines internet, telephone and television services, all operated from the same box

${ }^{3}$ Telesites are internet pages which can be consulted directly on television through Freebox

${ }^{4}$ ADUF is a not for profit association which manages the linkages between Free and its users and communities.
} 
brand), and show a Freebox on their first page.Iliad is considered one of the most innovative service providers on the internet, and as marketing the best offer in terms of quality/price. Iliad has held the Freebox price the same for 6 years, and its CEO regularly defends the interests of the 'Freenautes' against those of Iliad'sshareholders, which has strengthened community members' loyalties, even though Iliad's own web sites do not promote its communities' sites.

\subsection{Propellerhead}

Founded in the 1994, Propellerhead is a computer-assisted music software editing package which offers users a virtual recording studio including a range of tools - recorder, mixer, sampler, synthesizer and sound effects. In 2007, it marketed Rebirth BB-338, a synthesizer for creating Acid and Techno music, and currently markets the virtual studio Reasonwhich includes a sound library to support users'composition efforts;Record for recording and mixing inputs from musical instruments; and Recycle for creating sound loops. After its original Rebirth application was hacked by its users, Propellerhead opened up part of its code and supplied tools for modifying the sound bank and its interfaces, and its musician users have subsequently made hundreds of modifications (called Refills) which together now constitute an original music creation system which features an associated sound bank and graphic resources. Propellerhead regularly makes bundle offers available via communitycreated Refills sites (a hundred had been released by the end of 2010), and also gives its seal of approval to Refills supplied by professional musicians for sale on such sites. In all, the user community comprises some fifty user-managed sites, as well as the company's own community sites (which handled 77,000 messages in 2010) where users discuss and exchange ideas and content, give each other advice and encouragement (via text or video) on how to use the software, propose ideas for its further evolution and organize composition competitions. Propellerhead employees interact regularly with theiruser communities about 
software evolution and development problems via theirforums, which give the most experienced users the chance to propose ideas and solutions to the company's software developers, and meet members face to face during Propellerhead Tours, a cross between software demos and group music performances. Propellerhead has integrated the most innovative user ideas into its new software versions, including responding to wide calls for the introduction of sequencers, and offering a mouse wheel as an easier tool to manage music creation than a keyboard. The identities of Propellerhead and its community have become intertwined: the company provides clear links from its website to those of its community sites, and has even created a 'museum' site dedicated to its original synthesizer Rebirth, which it ceased marketing in $2010^{5}$.

\subsection{MySQL}

MySQL created proprietary software for managing relational data bases, which together with its associated programming language PHP -is used by the majority of web servers (more than 10 million in 2008). MySQL AB was bought out by Sun in 2008, which was in turn bought up by Oracle in 2009. The software is distributed with two different licenses, depending on how it is used: the GPL license (for non-commercial applications) is free, and there is also a proprietary license for commercial applications. MySQL was created by three members of the open source communitywho had contributed most actively to its development, and its community is made up of many developers (estimated at 6 million in 2010), grouped together on the official siteand about a hundred peripheral sites. The official site hosts a very active forum (230,000 messages in 2010), a bug base, documentation, blogs, and a space for promoting and following up developments. At the community level, MySQL

\footnotetext{
${ }^{5}$ This software was reedited in 2011 for the Ipad tablet
} 
appealed above all to users with development skills, and those who were most active in writing code, contributing to forums and conferences, and sending instant messages every year were designated as 'Guides' and their names posted on the official site. These developers proposed and wrote new functions for MySQL, depending on their needs, and others emerged during community discussions, with MySQL controlling and certifying the code developed by the community. Company employees have beenstrongly involved in forum discussions, and organized regular training sessions and demo tours to meet developers and promote MySQL applications. Again, the community is an integral part of the identity of MySQL and its site uses the same graphic identity as the firm's web site. Sun retained the GPL license after buying the company in 2008, althoughthe company's founders and main developers left the firm.

The four cases highlight the interrelationships with different communities. They all emphasize an original route of co-creation along the three phases of innovation development (design, production and post-production): online user community Innovation.

The research design, based on two original case studies and two secondary case studies has of course limitations. First of all, it focuses only on videogames while digital creative industries are larger than just games. Second, the paper deals with a limited number of cases. However, the main focus remains digitalization, which is common to all the subsectors of the digital creative. In addition, in the discussion, the generalization is mainly based on the mechanisms rather than dedicated empirical results.

\section{RESULTS}

The mechanics of innovation in collaboration with online user communities differfrom lead user patterns, in terms of how the firm manages not just its own innovation processes, but also its relationship withits communities and the degree to which it monitors the whole innovation process beyond its boundaries, the co-creation process, the respective 
contributions of firm and community, and finally the identities of the two entities.

Our data analysis identified a long list of items related to the management of innovation when user communities are involved. The transformation of innovation management is characterized by three elements: permeabilityof firm boundaries;opening of products and services to community inputand reducing or reorganizing intellectual property rights; and reshaping organizational and product identities.Firms open their boundaries to involve users in innovation process, open their product and service boundaries to foster and develop their users' creative abilities and integrate their contributions directly into the firms' development efforts, and open their identity boundaries to build common identities with their communities around the product/ service and to promote themselves as community-friendly companies. All these processes allow the companies to benefit from their users'contributions throughout the innovation process.

\subsection{Opening firm boundaries}

Openingcompany boundaries consists of setting up 'crossover' points in those boundaries to establish direct links with users so as to involve them in the innovation process. Our data (summarized in Table 3) shows that firms use three activities to open their boundaries: conversing with users;sharing tasks;and sharingknowledge.

A company's boundaries may be both physical (offices and production process) and virtual (web site and social network), and it will need to set up boundary objects ('doors') $[37,38]$ - such as discussion areas - for exchanging opinions and ideas and for giving advice on the products or services. By this means, the firm engages inconversations with users. Theseconversations commonly take the place on internet forums where users and employees can discuss products and services and the problems users encounter, as well as community events, and the exchange of tutorials and advice between users are seen as part of the firm's after-sales service. Analyzing these forums -usually situated on the company web site 
(Trackmania, MySQL, Proppelerhead), or on the community sites (Freebox) - enables a company to identify new needs, new uses and new ideas at the design phase. Regular face-toface meetings with community leaders are also occasions where forthcoming productscan be presented andideas for improvements and innovations discussed(Freebox, Trackmania). This is an important phase, in which the company can reshape and adapt its product design, although such interactions are not completely original and replicate howthe company sources and develops knowledge and ideas within its internal environment. In this framework, users do not participate directly in the production process, but act as a source of ideas and play a 'tester' role[2].

Opening boundaries in this way also involves opening production, by making development follow-ups (MySQL), beta version tests (Propellerhead, Trackmania) or information about bugs (Freebox) available to platform users. Community users and firm developers interact tosharetasks, and the integration of community users into the firm innovation processes facilitates exchanges between the two types of organization. Companies (e.g., Trackmania) may recruit leaders to moderate company/community exchanges, and these actorsact as gatekeepers, whilethe boundaries between community and firm are maintained. In some cases (e.g., MySQL) it is community leaders themselves who set up the firms. However, if the firm's existing boundaries are too strong, and their objectives too different from those of users, the firm may lose contact with its community and so fail to recruit community members, or to take advantage of their innovation potential. But when firm boundaries arehighlypermeable, information circulation between users and firm developers is fluid, the innovation process is opened, and thefirm managesthe relationship with its users, integrating heterogeneous direct contributions from users who are not part of the firm, so that the firms and user communities shareknowledge. At this stage, the firm mainly interacts with those community users and actors who propose innovations. Sharing 
communication platforms is a way for firms to address community members and to animate the community through the organization of recurring events, beta testing products and prototypes. Boundaries with online communities becomeeven more permeable where members' presence is digital: firm developers can be at work but at the same timeremain connected as community members - users can play and develop simultaneously. Firm creators and developers have often been players, users and active members of communities. What is new with digitization of interactions is that they are playing the two roles simultaneously, involved in the company and in user communities at the same time. Online communities enhance the fluidity of user/developer interactions, leading to greater alignmentbetween firm and community objectives and challengingthe separation of identities. They have multiple concurrent identities, with instant micro-role transition which is invisible from the outside $[15,39,40]$.While openness and fluidity betweenfirms and communities can lead to the convergence of both objectives and identities, diversity is still needed to stimulate creativity and to propose new usages.

Insert Table 3 here

\subsection{Opening product and service boundaries, sharingownership}

Managing co-creation involves firms opening their product or service boundaries so as to encourage the creation of new content and new functionalities, controlling user community contributions to guarantee product and service quality, and enhancing the status of the most active contributors to maintain their motivation and involvement, so that they can help transform the firm's products, software and services to provide it with enhanced versions to sell on the market. Our analysis indicates that firms use three activities to opening their product and service boundaries:supporting users' creativity; taking new uses into 
account; and supporting communities. Table 4summarizes our data.

The firm may open its products just to user communities or to outside contributors in general, and such 'opening-up' may be via offering open source licenses, or it may promotecommunity interactions by providing users with toolkits with which they can create content and set up events within or around the product or service. Such toolkits allow community members to involve themselves in the creative process ofdeveloping innovations, and firms use them to promote and 'harvest' user innovations[41, 42]; to organize competitions of ideas $[43,44]$; to design new products in collaboration with users [45];to gain user-created content directly [17]; or to adapt products to meet particular needs as expressed by their users [46, 47]. The firmsupports creationbyusers bymaking new tools available. Innovation within and in collaboration with user communities extends this logic to allow communitymembers to participate directly in the design and development of products or services. When firms provide theiruser communities with tools for community animation, the firm is acknowledging and paying tribute to how much it benefits from theirmembers' expertise and creativity. The difference of objectives between the firm and the community remain clear - when a community modifies products directly or is deeply involved in the development process, benefits are shared according to the respective objectives of the firms (turnover and profits) and the community (better adapted products or services).

Firms open their product designto user communities during the development process, but users can also be involved in the production and post-production processes, by contributing innovative content (Trackmania, Propperlerhead), and by developing product functionalities (MySQL, Freebox). Analyzing users' creations can help a company identify new modes of use and new needs, and introduce new functions into upcoming versions to meet them (Trackmania and Proppelerhead). Users proposenew usesof existing products as part of their input into developing new product versions. The creative dimension in 
creativeindustries is twofold: technological creation (adapting existing products or games) and artistic creation (proposing new scenarios, new environments, and new ways to play games, or use products). Online communities can use web 2.0 logic to amend products, so that they are never completely stable, andthe continuous implementation of add-ons changes and extendsproduct usage.As products are held on-line, and can be adapted and modified by users, the boundaries between production and post-production become fuzzy, leading to continuous product renewal and continuous flexibility of firm/community boundaries.

Firms and communities also interacton the community animation side, which involves organizing community events connected with the product or service - such as international competitions, (Trackmania), demonstration tours (Proppelerhead), or training (MySQL) - to attract new members, to stimulate and recognize members' status and encourage them to create new content.In such ways, the company supports the community. Event organizing tools can also be integrated into the same toolkitscommunity members use to create innovations (e.g., Trackmania). The quality of members' contributions can be directly and automatically verified by the toolkit (Nadeo), or theirefforts can be validated after being uploaded onto the company's site. (MySQL and Propellerhead). Users' status can be recognized and increased through such designations as community leaders (Freebox) or 'best contributors' (MySQL), or by company developers acting as forum moderators (Trackmania, Proppelerhead, MySQL) Trackmania has instituted a virtual money unit - a 'copper' - to reward participation in competitions and content creation, and users can spend this currency on buying elements created by other players from within the game itself.The firm and the community share ownership of the community-improved product, but the rewards differ: they are mostly monetary for the firm and mostly symbolic for the community (recognition, premium access, etc.).Thus firms partially sharethe intellectual properties of component of the product, but not its appropriation. Community members may benefit from privileges and 
recognition but their main rewards are usually not monetary. The support of the community provided by the firm is not only a way to stimulate innovation but also to orchestrate the community to keep the monetary appropriation of returns possible, as the community values other sorts of returnsmore.

Insert Table 4 here

\subsection{Identity convergence on product or services, not on firms and community}

The community and the firm are two separate entities - although organized around the same focus, they have different objectives. While the firm aims to create and appropriate rents by making the best offer to the market, the community aims to organize matters so that users benefit from the focal game or software, and to propose or realize improvements to increase that benefit. Our data indicate that firms use three activities to manage identity issues:sharing identifying elements;building common values;and sharing values. Table5 summarizes our data on identity boundaries.

User communities and firms have separate identities based on rituals, events, and images,and projects on which the two collaborate will also have their distinctidentities, perhaps expressed in graphics and logos - these are often shared between firm and community, even if their separate identities remain different. But the two sides work together, so that there is a considerable amount of identity cross-over - thus the firm and the community share identifying elements. Firm websites support virtual communities' identities (Propperhead, Trackmania and MySQL): community and company domains names often have common elements - 'tm' for Trackmania and 'Free' for Freebox - and companies can share their domain names with their community, e.g., 'freeplayer.org' for the Freebox community site. The most active community internet sites can also be linked directly to 
company web sites (Proppelerhead, Trackmania), even from within the product, as in the Trackmania game's 'Manialink' function. Compared with these cases, the Freebox community is not integrated into its company's identity, althoughlliad plays on its community'simage in itsadvertising material, which systematically featuresone 'geek' who is more astute than others.

Interactions between company and communities foster a sense of common values. Discussions in forums or interviews on community sitescontribute to the convergence of values and shared objectives between firms and communities. These values are reinforced when members belonging to both, when a company recruits community leaders to manage relations between the two entities (Trackmania), or when it is actually created by members of a pre-existing community (MySQL)

A community interprets company activity according to its own values -from its viewpoint, the company's products and services are parts of its identity. Trackmania, Propellerhead and MySQL are not considered as purely commercial firms: passions for games, music and software development are shared between employees and community members, and company founders and employees are considered - and in many cases actually are - real user community members. From the company's perspective, its task is to develop and market the best possible games, the most useful music software or the most efficient database system, at the lowest possible cost. The community's specific objectives are the ability to play, to create and to share with others - respecting those objectives is important if firms wish to maintain their community members' interest in collaborating.

The common identity is stronger in the Trackmania and MySQL cases, and these firms have adopted economic models that are partially cost free to preserve and strengthen this common identity. Trackmania regularly offers free add-ons and new game versions, while MySQL's double license system means the software is free to individual users anyway. 
In situations where commercial market moves have led the commercial model to supplant the free model, the respective identities of the firm and the community becomeclearer and may even compete against each other. The acquisition of MySQL by Sun, and then by Oracle, provoked the departure of the founders, and led the community persistently to question Oracle's intentions. Iliad's attempt to chargefor upgrading its Freebox device led to strong community protests, forcing the CEO to backtrack and propose a much lower tariff.

Firms and communities act as balancing centers of power, and manage specific and converging identities. But, beyond their differences, they recognize themselves as part of the same wider 'family' of sharedvalues, whose identitiesbecome incorporated in the product(s). One of the key results is to split the ideas of identity and where it is embodied: the convergence of firm and community identities can lead to homogeneity of attitude towards the product/service, which will eventually reduce creativity, and (in the mid-term)risks weakening the community's 'pull' role. Whereidentity is embodied in the product, firm and communities add different elements to that identity, leading to better diffusion, but keeping firm and community identities separated.

As digitization proceeds, the user community canbecome thenew locus of innovation in the creative industries,blurring the distinctionbetween production and post-production. Users are involved in developing products which are only stable for short periods before they are further refreshed: firms benefit from users' involvement to adapt their platforms to give them wider market appeal, and communities benefit as the product serves their needs more accurately. This continuum between creation, production and post-production allows communities and firm to keep their own identities and at the same time to collaboratein the on-going product use and utility dimensions.

Insert Table 5 here 


\section{DISCUSSION}

While networks werethe locus of innovation for science based industries (Powell et al., 1996), online user communities are becoming the locus of innovation in the digital creative industries, where creativity can be a bottleneck in the innovation process. Fluidity of interactions and fuzzy boundaries between production and post-production are the characteristicsof a new model of innovation in such contexts. We have examined four such settings, moving from innovation through collaboration, to innovation via communities to coinnovation with communities, where firms have a dual role in simultaneously opening up theirboundaries and in managing co-innovation on the one hand and monitoring and orchestrating user communities on the other.

\subsection{Managing the innovation process within firm}

The firm remains central in orchestratingcommunities as loci of innovation. Managing the innovation process involves both managing the firm's internal processes and opening themup to build on contributions fromonline usercommunities. Decisions need to be made at different levels: the first is for the firm to open up its development process, as co-innovation with a user community involves opening the company's boundaries, its products and services, and its identity to facilitate that innovation. But a firm opening its innovation process risks losing control of it, so decisions have to be made about the appropriate degree of openness. Dahlander and Gann argue that the more open firms are in revealing their processes, the greater the community's contribution can be. Opening the innovation process implies that the firm losses the control on the development process, on the direction where the product goes and on the product life cycle. As it is risky,such opening willalways remain partial, and how firm/community links are managed differs according to the companies and their situations [48].

The second decision is to identify which elements are to be opened and which should 
remain purely internal. For example, whether the source code of software is open (so the product is completely customizable); or remains closed, but the product/service is open to user contributions, withsome kind of communication channel established via which users can give feedback which developers can use in creating new offerings. Nadeo has only opened up the content areaof its software -the game code remains its property. The company has institutionalized its relationship and interactions with its community via the Trackmania toolkit,which ensures that connections between the two arepartly automated. Propellerhead has only partly opened up the content dimension-proposed Refills have to be authorized by the firm before they are posted on the firm's site. MySQL has opened up all its codes, but community-created code has to be authorized by the company before being included in new software versions. Iliad has opened up very little -onlya few settings are accessible to community developers. So (to different extents) all these firms have limited the amount of their openness so as to keep control of theirinnovation processes, and in certain cases, to retaintheir control over their intellectual property. But opening the product alone is not enough to reap the full rewards of co-innovations with users -the innovation process must be opened too, as well as the company's boundaries and identity.

The last decision is how to appropriate and share the benefits of co-innovation, which may or may not be monetary. Firms and user communities are not after the same objectives: their definitions of value will differ, and the firm must understand what is specifically valuable to user communities, which may take the form of symbolic rewards, improved tools for managing the community or for playing/using/modifying the product, etc. When the firm considers offering its community only monetary rewards, it may disappoint the community members who are expecting recognition and rewards such as individual service or premium access, additional access for the community members, discount or monetary rewards (Cf. Apple apps model), or additional pleasure to play upgraded games, etc. Improved tools, 
support to organize events and activities are also important rewards for community members who value both individual symbolic recognition and community recognition.

The appropriation of the returns may include a symbolic dimension related to the identity of the product. Is the co-developed product only associated with the firm or is it also attributed to the user community - in which how is its contribution recognized? Blurring the boundaries between different development stages (production and post-production)reinforces the converging identity between user communities and firms, but some level of distinction between the two will be required to avoid over-convergence.

The digitization and virtualization of interactions between creative industry firms and their communities givestheir relationship greater fluidity,andhas radically changedhow innovation is managed within such firms, so it is no longer about the simple launch of a new product, but has becomeabout firms co-developing on-going products with their user communities.

\subsection{Orchestrating the community}

Achieving innovation with user communities requires the firm to balance opening up its innovation and development processes - but at the same time giving up some level of control over those processes - and maybe even of part of their returns - against the value involving their user communities in co-innovation cancreate. The temptation for companies is to try to combine monitoring and value creation by directly controlling their communities' activities, but such actions can provoke conflicts with their members [49]. Effectively, such control means integrating the community within the firm, but Danneels has shown the development of too strong ties with existing clients slows down the development of new products, and can lead to the sterilization of the community in the medium run by reducing diversity and external sources of innovation[50]. So companies more frequently adopt the role of orchestrating their communities' activities, which avoids this problem and respects the 
specific identities of each player, and tries to ensure they continue to collaborate fruitfully, each contributing their own expertise. Thus, to maintain both parties'freedom of action, the firm has to manage a combination of strong and weak ties. When a company adopts an identity that is partially shared with its community, its degree of freedom is reduced, as it has to negotiate each evolution of its strategy with the community. Managing this kind of 'common' identity involves the firm in partially adopting the community model, discussing all the product and service evolutions it envisages with community members, explaining and justifying the choices it makesto them.

The firm may organize the co-existence between convergence of values and differentiation of identities by reinforcing product identity and image, in which both the community and the firm. Blurring the boundary between production and post-production reinforces the role of product identity - so that it is no longer identified as a 'finished' item, but as an on-going product resulting from co-innovation between the firm and the community, which incorporates part of their respective values and objectives. This enables each side to keep its own identity, but also limits the degree of freedom of the firm. (A good example is the reaction of the Free community when Free tried to raise its prices - a policy it quickly reversed in the face of community opposition.) The notion of the 'on-going product'represents as a boundary object which incorporates the identities of the codevelopers [51].

In the long-term, firm/community relationships have a tendency to become institutionalized: events and meetings reoccur, and common identitiesbecomes 'locked',reducing its development possibilities. In three of our cases (Trackmania, Propellerhead and MySQL), the communitiesare partly hosted by the firms, reinforcing the institutionalization of suchconnections. In the case of Freebox, the relationship is more distant and interactions remain limited but are still highlyinstitutionalized - meetings with 
users and demo tours are regular events - and the firm meets community leaders on its premises. The community expects the firm will seek its advice before launching new software or hardware, and community forums will includediscussions on their evolution,as the community hasprivileged access to relevant company information and its members test new versions' beta codes. So the company loses part of its strategic freedom, as it cannot make decisions without consulting the community. Once the product is completely finalized,to limit potential changes on the product, the company might be tempted to limit the connections with the community, risking conflict with frustrated members, a situation that may also arise when (as in the case of MySQL) the company is bought out by an international group.

In the case of Trackmania, this pattern of continuous co-innovation in collaboration with a user community affects the product life cycle: the product is constantly evolving, and has remained as a beta version for a long time - there have been 7 versions of Trackmania over 8 years, but without the game reaching its final phase. Freebox functionalities have also evolved continuously over 10 years, ensuring it remains one of the most innovative and cheapest set-top boxes on the telecom market. In the same way, involving an active community in the innovation process has allowed MySQL to continuously renew its product/service offer and maintain its innovativeness over a long period, so itsdatabase software is constantly being enhanced with new functions. A similar logic has been involved in the production of series of console games, where product versions follow on from one another, with the same basic structure, but including new functionalities as the design progresses, sometimes extending their target market.

\section{CONCLUSION}

We have argued that online communities of users are the new locus of innovation indigital creative industries, and that firms involved in this style of co-innovationmust 
develop specific and strong ties with user communitiesto capture their innovative contributions. Co-innovation with communities requires companies to open up their boundaries, products and services, and company identities, and to successfully manage the relationships between firm and community; their users' contributions and their respective identities. Our results show that, to increase the capacity for innovation, the collaboration must be established withinboth organizations, and across all functions and types of innovation: technological innovation, innovative uses and content. This requires firms to develop new knowledge and skills, not only to develop experience at managing $\mathrm{R} \& \mathrm{D}$, but also in managing boundary and identity issues.

Involving whole user communities in the innovation process also renews and complements the 'lead user' concept, as defined by von Hippel. Methods for detecting isolated lead users are expensive, and they may only be sporadically involved in innovation[52]. When the firm co-innovates with online user community the question is no longer about identifying lead users, but how to manage interrelations with the community, to orchestrate and to find ways to maintain and to benefit from heterogeneity between the firm and the community in terms of co-innovation. We argue that innovating with online user communitiesbased on fluid interrelations changes what the firm considers as 'its' product or service. When users are involved, when user communities innovate and are able to adaptthe product and its possible uses, the firm must accept the notion of marketing'on-going' products or services that can be specified or modifiedby users. Innovating in collaboration with users implies that firms no longer fully control product/service development, but at the same time being connected to user communities means they know their users better. The firm does not just launch new products without taking user community input into account. As the boundaries between production and post-production are blurred, the firm can control neither the community - which requires independence to be lively - nor product development, which 
is on-going. Thus the management of innovation evolves, from control of users/partners and products to orchestration of communities of users who are co-developing the product.

Further research should study the differences between digital creative industries and otherindustrial sectors. Additional studies should also attempt to find the way to manage innovation with several user communities and attempt to identify hindrances to this type of innovation process. 


\section{Bibliography}

[1] L. Dahlander, M. Magnusson, How do Firms Make Use of Open Source Communities?, Long Range Planning, 41 (2008) 629-649.

[2] T. Burger-Helmchen, P. Cohendet, User Community and Social Software in the Video Game Industry, Long Range Planning, 44 (2012) 317-343.

[3] S. Faraj, S.L. Jarvenpaa, A. Majchrzak, Knowledge Collaboration in Online Communities, Organization Science, 22 (2011) 1224-1239.

[4] S.L. Jarvenpaa, K.R. Lang, Boundary Management in Online Communities: Case Studies of the Nine Inch Nails and ccMixter Music Remix Sites, Long Range Planning, 44 (2011) 440-457.

[5] L. Dahlander, M.G. Magnusson, Relationships between open source software companies and communities: Observations from Nordic firms, Research Policy, 34 (2005) 481.

[6] C. Dhanaraj, A. Parkhe, Orchestrating Innovation Networks, Academy of Management Review, 31 (2006) 659-669.

[7] L.B. Jeppesen, K. Laursen, The role of lead users in knowledge sharing, Research Policy, 38 (2009) 1582-1589.

[8] G. Schreyogg, J. Sydow, Organizing for Fluidity? Dilemmas of New Organizational Forms, Organization Science, 21 (2010) 1251-1262.

[9] E. Von Hippel, Lead users: a source of novel product concepts, Management Science, 32 (1986) 791.

[10] G.L. Lilien, P.D. Morrison, K. Searls, M. Sonnack, E. Von Hippel, Performance Assessment of the Lead User Idea-Generation Process for New Product Development, Management Science, 48 (2002) 1042.

[11] C. Lüthje, Characteristics of innovating users in a consumer goods field: An empirical study of sport-related product consumers, Technovation, 24 (2004) 683.

[12] D. Mahr, A. Lievens, Virtual Lead User Communities: Drivers of Knowledge Creation for Innovation, Research Policy, 41 (2012) 167-177.

[13] D.A. Pitta, D. Fowler, Online consumer communities and their value to new product developers, Journal of Brand and product Management, 14 (2005) 283-291.

[14] J. Battilana, S. Dorado, Building Sustainable Hybrid Organizations: The Case of Commercial Microfinance Organizations, Academy of Management Journal, 6 (2010) 1419-1440.

[15] N. Battard, V. Mangematin, Idiosyncratic distances: Practices around mobile technologies, Technological Forecasting and Social Change, 80 (2013) 231-242.

[16] C. Sundaramurthy, G.E. Kreiner, Governing by Managing Identity Boundaries : The case of Family Business, Entrepreneurship Theory and Practice, May (2008) 415-436.

[17] L.B. Jeppesen, L. Frederiksen, Why Do Users Contribute to Firm-Hosted User Communities? The Case of Computer-Controlled Music Instruments, Organization Science, 17 (2006) 45-63.

[18] G. Hertel, S. Niedner, S. Herrmann, Motivation of software developers in Open Source 
projects: an Internet-based survey of contributors to the Linux kernel, Research Policy, 32 (2003) 1159-1177.

[19] E. Raymond, The Cathedral and the Bazaar., in, 1998.

[20] C. Lüthje, C. Herstatt, The Lead User method: an outline of empirical findings and issues for future research, R\&D Management, 34 (2004) 553.

[21] C. Luthje, C. Herstatt, E. Von Hippel, User-innovators and "local" information: The case of Mountain Biking, Research Policy, 34 (2005) 951-965.

[22] N. Franke, S. Shah, How communities support innovative activities: an exploration of assistance and sharing among end-users, Research Policy, 32 (2003) 157-178.

[23] N. Franke, E. von Hippel, M. Schreier, Finding Commercially Attractive User Innovations: A Test of Lead-User Theory, Journal of Product Innovation Management, 23 (2006) 301-315.

[24] M. Osterloh, S. Rota, Open source software development: Just another case of collective invention?, Research Policy, 36 (2007) 157-171.

[25] J. Lerner, J. Tirole, Some Simple Economics of Open Source, Journal of Industrial Economics, 50 (2002) 197.

[26] C. Wiertz, K. de Ruyter, Beyond the Call of Duty: Why Customers Contribute to Firmhosted Commercial Online Communities, Organization Studies (01708406), 28 (2007) 347-376.

[27] S.N. O'Mahony, F. Ferraro, The emergence of governance in an open source community, Academy of Management Journal, 50 (2007) 1079-1106.

[28] A. Hemetsberger, C. Reinhardt, Collective Development in Open-Source Communities: An Activity Theoretical Perspective on Successful Online Collaboration, Organization Studies (01708406), 30 (2009) 987-1008.

[29] K.J. Stewart, S. Gosain, The impact of ideology on effectiveness in open-source software development teams, MIS Quaterly, 30 (2006) 291-314.

[30] E. Raymond, The Magic Cauldron, in, 1999.

[31] L. Dahlander, Managing Beyond Firm Boundaries : leveraging user innovation networks, in: Department of Technology Management and Economics, Chalmers University of technology, Gothenburg, 2006, pp. 177.

[32] C. Hienerth, P. Keinz, C. Lettl, Exploring the Nature and Implementation Process of UserCentric Business Models, Long Range Planning, 44 (2011) 344-374.

[33] K.M. Eisenhardt, Building Theories from Case Study Research, Academy of Management Review, 14 (1989) 532.

[34] L. Dahlander, L. Frederiksen, The Core and Cosmopolitans: A Relational View of Innovation in User Communities, Organization Science, 23 (2012) 988-1007.

[35] K. Weick, The collapse of sensemaking in organizations : the mann gulch disaster, Administrative Science Quarterly, 38 (1993) 628-652.

[36] A. Strauss, J. Corbin, Basics of qualitative research: techniques and procedures for developing grounded theory, Sage Publications, Thousand Oaks, 1998.

[37] R. Duymedjian, C.-C. Rüling, Towards a Foundation of Bricolage in Organization and Management Theory, Organization Studies, 31 (2010) 133-151. 
[38] P. Carlile, A Pragmatic View of Knowledge and Boundaries: Boundary Objects in New Product Development, Organization Science, 13 (2002) 442-457.

[39] C. Licoppe, Connected' presence: the emergence of a new repertoire for managing social relationships in a changing communication technoscape, Environment and Planning D: Society and Space, 22 (2004) 135-156.

[40] B.E. Ashforth, G.E. Kreiner, M. Fugate, All in a day's work: boundaries and micro role transitions, Academy of Management Review, 25 (2000) 472.

[41] E. Von Hippel, Perspective: User toolkits for innovation, Journal of Product Innovation Management, 18 (2001) 247-257.

[42] E. Von Hippel, R. Katz, Shifting Innovation to Users via Toolkits, Management Science, 48 (2002) 821-833.

[43] W. Ebner, J.M. Leimeister, H. Krcmar, Community engineering for innovations: the ideas competition as a method to nurture a virtual community for innovations, R\&D Management, 39 (2009) 342-356.

[44] F.T. Piller, D. Walcher, Toolkits for idea competitions: a novel method to integrate users in new product development, R\&D Management, 36 (2006) 307-318.

[45] J. Fuller, G. Jawecki, H. Muhlbacher, Innovation creation by online basketball communities, Journal of Business Research, 60 (2007) 60-71.

[46] N. Franke, F. Piller, Value Creation by Toolkits for User Innovation and Design: The Case of the Watch Market, Journal of Product Innovation Management, 21 (2004) 401. 45 .

[47] C. Berger, F.T. Piller, Customers as co-designers, Manufacturing Engineer, 82 (2003) 42-

[48] L. Dahlander, D.M. Gann, How open is innovation?, Research Policy, 39 (2010) 699-709.

[49] L. Dahlander, Appropriation and appropriability in open source software, International Journal of Innovation Management, 9 (2005) 259.

[50] E. Danneels, Tight-loose coupling with customers: the enactment of customer orientation, Strategic Management Journal, 24 (2003) 559.

[51] B. Simpson, B. Carroll, Re-viewing 'Role' in Processes of Identity Construction, Organization, 15 (2008) 29-50.

[52] E. Von Hippel, Breakthroughs to Order at 3M, in: MIT Sloan School of Management, MIT, 1999. 
Table 1 - Characteristics of lead usersand online user communities as loci of innovation

Lead user as a source of innovation $\quad$ Online user communities as a locus of innovation

\begin{tabular}{lll}
\hline Who & $\begin{array}{l}\text { Individual users who have advanced } \\
\text { requirements and who benefit from } \\
\text { their satisfaction }\end{array}$ & $\begin{array}{l}\text { Interplay between developers within } \\
\text { firms and users within communities }\end{array}$ \\
$\begin{array}{l}\text { Who manages } \\
\text { the innovation } \\
\text { process } \\
\text { Alignment }\end{array}$ & $\begin{array}{l}\text { The firm manages the innovation } \\
\text { process and test new products or } \\
\text { services with lead users }\end{array}$ & $\begin{array}{l}\text { User's community is pulling } \\
\text { innovation and act to modify objects. }\end{array}$ \\
Boundaries & $\begin{array}{l}\text { Clear boundaries of the firm which } \\
\text { manages the innovation process }\end{array}$ & $\begin{array}{l}\text { Fluid boundaries between firms and } \\
\text { communities. Boundaries are } \\
\text { evolving. }\end{array}$ \\
$\begin{array}{l}\text { What is } \\
\text { managing } \\
\text { innovation }\end{array}$ & $\begin{array}{l}\text { The management of innovation is the } \\
\text { management of projects which may } \\
\text { source ideas within user community. }\end{array}$ & $\begin{array}{l}\text { Management of community } \\
\text { interactions, with partial release of } \\
\text { on-going products. }\end{array}$ \\
Risks & Choosing un-relevant lead users & $\begin{array}{l}\text { Problem of strategic alignment } \\
\text { between firm and community }\end{array}$
\end{tabular}


Table 2 - Case Characteristics and Data

\begin{tabular}{|c|c|c|c|c|}
\hline & Trackmania & Propellerhead & MySQL & Freebox \\
\hline Activity of firm & Video game & Music software & Database software & Internet box \\
\hline Community size & $\begin{array}{l}\text { Forumin web site of the } \\
\text { publisherand hundreds of web sitesof } \\
\text { playersfor discussion } \\
\text { andexchangeof content. } \\
34000 \text { registered in official forum } \\
\text { in } 2008 \text {. }\end{array}$ & $\begin{array}{l}\text { Web siteof the publisher anda } \\
\text { hundredsiteuserdiscussion and } \\
\text { exchangeof content. } \\
3850 \text { members (see Jespersen } \\
\text { and Frederiksen, 2006) }\end{array}$ & $\begin{array}{l}\text { Web siteof the publisher } \\
\text { andhundreds of sitesandforums } \\
\text { dedicated toMySQL. } \\
230000 \text { posts in official forum } \\
\text { in } 2010 \text {. We estimate the } \\
\text { registered at } 23000 \text {. }\end{array}$ & $\begin{array}{l}\text { A dozenweb siteusers. } \\
\text { In } 2008 \text {, the top } \\
5 \text { sites, } 200 \text { 000registered inthe } \\
\text { forums. }\end{array}$ \\
\hline Device & $\begin{array}{l}\text { Forums, user toolkit, siteto sharing } \\
\text { of content }\end{array}$ & $\begin{array}{l}\text { Forums, user toolkit, siteto } \\
\text { sharing of content }\end{array}$ & $\begin{array}{l}\text { Fora,open sourcelanguage, } \\
\text { code-sharing site. }\end{array}$ & $\begin{array}{l}\text { Forums, open source } \\
\text { software,news site, TV } \\
\text { channelmanaged byusers }\end{array}$ \\
\hline Leaders & $\begin{array}{l}\text { Administratorsofthe most visited } \\
\text { sitesin thecommunity, } \\
\text { andmoderators of the official forum }\end{array}$ & $\begin{array}{l}\text { Administratorsofthe most } \\
\text { visited sitesin thecommunity, } \\
\text { andmoderators of the official } \\
\text { forum }\end{array}$ & $\begin{array}{l}\text { MySQLcreatorof language, } \\
\text { administrators of forums } \\
\text { anddevelopers"Guide"of the } \\
\text { community. }\end{array}$ & $\begin{array}{l}\text { Administratorsof sites } \\
\text { andforumsthe most visitedin } \\
\text { thecommunities }\end{array}$ \\
\hline Internal sources & $\begin{array}{l}16 \text { interviews - } \\
134 \text { pages }\end{array}$ & & & $\begin{array}{l}8 \text { interviews - } \\
115 \text { pages }\end{array}$ \\
\hline \multirow[t]{3}{*}{ External sources } & & Two research papers & $\begin{array}{l}\text { Three research papers and one } \\
\text { thesis }\end{array}$ & \\
\hline & 34000 posts & 77000 posts. & 230000 posts & 200000 posts \\
\hline & $\begin{array}{l}14 \text { interviews on blogs and } \\
\text { information websites } \\
2 \text { videos }\end{array}$ & $\begin{array}{l}\text { Storingcontribution toRebirth } \\
\text { software on the dedicated web } \\
\text { site, rebirth museum }\end{array}$ & Ten interviews in websites. & Ten interviews in websites. \\
\hline $\begin{array}{l}\text { Informants: } \\
\text { interviews and } \\
\text { papers }\end{array}$ & $\begin{array}{l}\text { General manager } \\
\text { Developer } \\
\text { Gamer } \\
\text { Active member of community }\end{array}$ & $\begin{array}{l}\text { General manager } \\
\text { Manager } \\
\text { Developer } \\
\text { Users }\end{array}$ & $\begin{array}{l}\text { General manager } \\
\text { Manager } \\
\text { Developer }\end{array}$ & $\begin{array}{l}\text { Leaders of community } \\
\text { General manager } \\
\text { Manager } \\
\text { Developer }\end{array}$ \\
\hline
\end{tabular}


Table 3 - Opening firm boundaries

\begin{tabular}{|c|c|c|c|c|}
\hline Activities & Conversing with users & Sharing tasks & Sharing knowledge & Results \\
\hline Definition & $\begin{array}{l}\text { Communicatingwith users on } \\
\text { internet, in small groups in the } \\
\text { company, or during community } \\
\text { events. }\end{array}$ & $\begin{array}{l}\text { Calling for contributions from } \\
\text { the users to participate in the } \\
\text { development of a new version } \\
\text { of the product Spontaneous } \\
\text { development by the users. }\end{array}$ & $\begin{array}{l}\text { Sharing knowledge of the } \\
\text { product between the company } \\
\text { and the users, and sharing } \\
\text { knowledge on the product's } \\
\text { uses among the users. }\end{array}$ & Involvement of users in the \\
\hline Outcomes & $\begin{array}{l}\text { Identification of needs, new uses, } \\
\text { ideas of new functions and } \\
\text { products. }\end{array}$ & $\begin{array}{l}\text { Externalization of the } \\
\text { development: codes, functions } \\
\text { and identification of bugs. }\end{array}$ & $\begin{array}{l}\text { Collective training on the use } \\
\text { of the product Identification } \\
\text { and problem solving. }\end{array}$ & innovation process \\
\hline Phase & Design & Production & Post-production & \\
\hline Plan of action & $\begin{array}{l}\text { Discussion forum and face to face } \\
\text { meetings }\end{array}$ & $\begin{array}{l}\text { Development platform. Free } \\
\text { access to code source }\end{array}$ & Mutual aid forum & \\
\hline Trackmania & $\begin{array}{l}\text { Propositions by the players for } \\
\text { improving the game (scores, circuit } \\
\text { exchanges, types of game) and tests } \\
\text { with players for developing the } \\
\text { game. } \\
\text { Regular meeting at Nadeo. }\end{array}$ & $\begin{array}{l}\text { Debugging of all the beta } \\
\text { versions of the different } \\
\text { versions of Trackmania. } \\
\text { Development of tools for } \\
\text { downloading and sharing } \\
\text { circuits. }\end{array}$ & $\begin{array}{l}\text { Writing tutorials. } \\
\text { Collective answers to } \\
\text { questions on the use of } \\
\text { Trackmania and the creation of } \\
\text { content }\end{array}$ & $\begin{array}{l}\text { Integration of user ideas into the } \\
\text { new versions of the game }\end{array}$ \\
\hline MySQL & $\begin{array}{l}\text { Propositions of new language } \\
\text { functions by the users in the forums }\end{array}$ & $\begin{array}{l}\text { Development for the users of } \\
\text { the new MySQL functions. } \\
\text { Debugging by users }\end{array}$ & $\begin{array}{l}\text { Collective answers to } \\
\text { questions on the development } \\
\text { of new functions and on the } \\
\text { use ofMySQL language }\end{array}$ & $\begin{array}{l}\text { A part of the development is } \\
\text { carried out by the users after } \\
\text { identifying new needs }\end{array}$ \\
\hline Propellerhead & $\begin{array}{l}\text { Propositions of new software } \\
\text { functions by the users (sequencer) } \\
\text { and test with users of the software } \\
\text { development project }\end{array}$ & $\begin{array}{l}\text { Debugging of all the beta } \\
\text { versions of the application. } \\
\text { Development of an interface to } \\
\text { connect Reason to videos }\end{array}$ & $\begin{array}{l}\text { Writing tutorials. } \\
\text { Collective answers to } \\
\text { questions on the use of } \\
\text { software and creation tools. }\end{array}$ & $\begin{array}{l}\text { Integration of user ideas into the } \\
\text { new versions of the software. }\end{array}$ \\
\hline Freebox & $\begin{array}{l}\text { Collecting ideas for improvements } \\
\text { and new functions.Presentation of } \\
\text { development projects during the } \\
\text { regular meetings with community } \\
\text { leaders }\end{array}$ & $\begin{array}{l}\text { Development by the users of } \\
\text { Freeplayer software mods } \\
\text { Debugging by the users }\end{array}$ & $\begin{array}{l}\text { Collective answers to } \\
\text { questions on the use of } \\
\text { Freebox. Installation problem } \\
\text { solving }\end{array}$ & $\begin{array}{l}\text { Transformation of the Freebox } \\
\text { into a multimedia platform } \\
\text { Community development. } \\
\text { After-sales service provided by } \\
\text { users }\end{array}$ \\
\hline
\end{tabular}


Table 4 - Opening products/services for co-creation

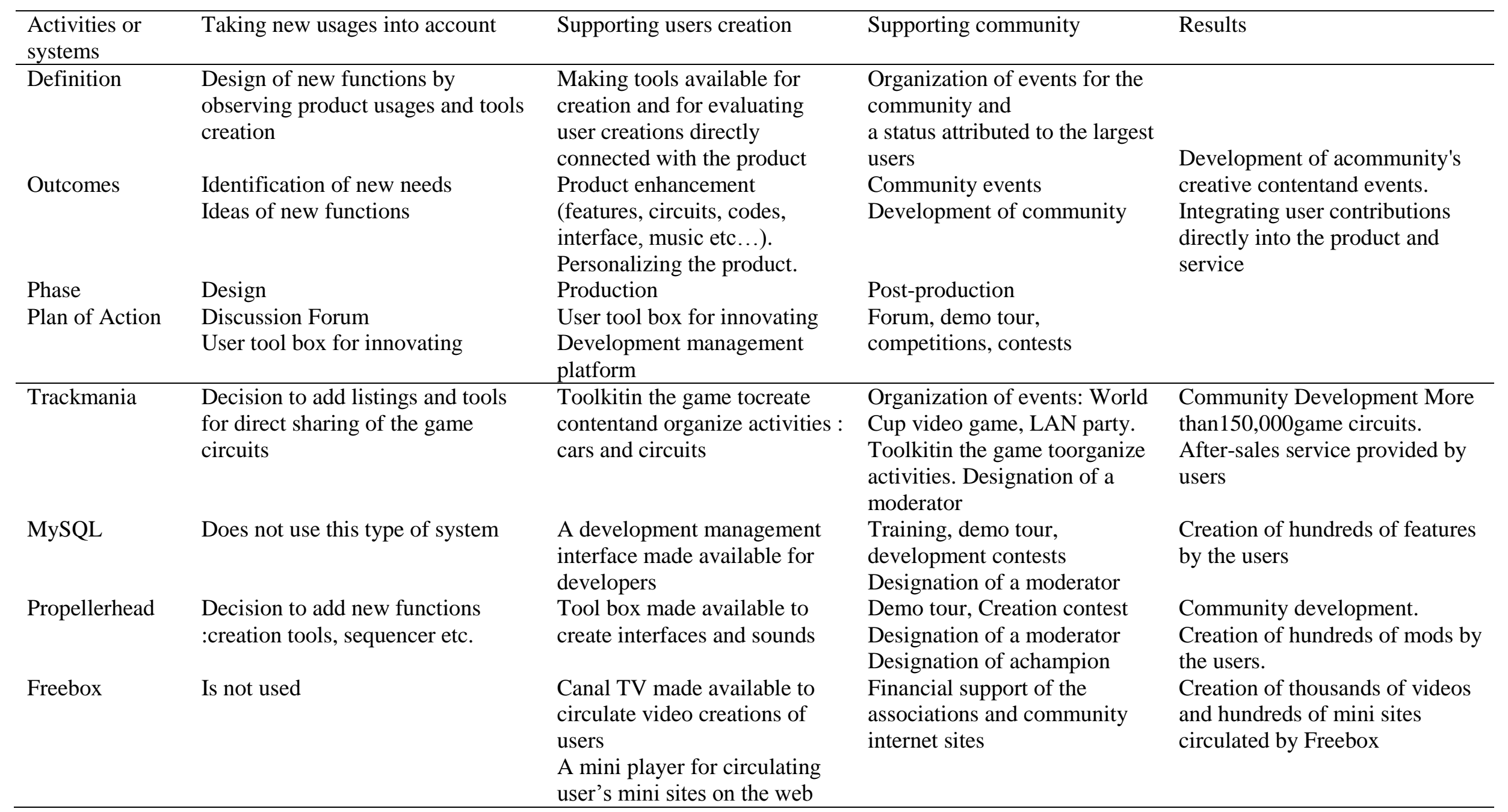


Table 5 - Identity convergence around products and services

\begin{tabular}{|c|c|c|c|c|}
\hline $\begin{array}{l}\text { Activities or } \\
\text { systems }\end{array}$ & Sharing identifying elements & Building common values & Sharing the value & Results \\
\hline Definition & $\begin{array}{l}\text { Sharing elements of identification } \\
\text { between thecommunity and the } \\
\text { company : history, visual, name and } \\
\text { internet address }\end{array}$ & $\begin{array}{l}\text { Exchange of common values } \\
\text { between the community and } \\
\text { the company embedded in } \\
\text { product or service identity. }\end{array}$ & $\begin{array}{l}\text { Users have free use of part of } \\
\text { the product and service, or a } \\
\text { low price is maintained over a } \\
\text { long period }\end{array}$ & $\begin{array}{l}\text { Development of a } \\
\text { communitycompany friendly }\end{array}$ \\
\hline Outcomes & Common identity & $\begin{array}{l}\text { Justification of the } \\
\text { contribution of users }\end{array}$ & Attractiveness of the product & \\
\hline Phase & All phases & All phases & All phases & \\
\hline Plan of action & $\begin{array}{l}\text { Company history. } \\
\text { Logos. } \\
\text { Name of the domain, Language } \\
\text { elements }\end{array}$ & $\begin{array}{l}\text { Post for the forum. Interviews } \\
\text { with company managers. } \\
\text { Meetings with the community } \\
\text { leaders }\end{array}$ & $\begin{array}{l}\text { Open source, limited version } \\
\text { free }\end{array}$ & \\
\hline Trackmania & $\begin{array}{l}\text { Circulation of colours and the } \\
\text { Trackmania logo on the community } \\
\text { sites. } \\
\text { Use of the TM root in the domain } \\
\text { name by all the community sites }\end{array}$ & $\begin{array}{l}\text { Creation of a TM spirit, shared } \\
\text { values between the company } \\
\text { and the community. } \\
\text { Involvement of company } \\
\text { members in the discussions on } \\
\text { community values in the } \\
\text { forums }\end{array}$ & $\begin{array}{l}\text { Free add-on editionand } \\
\text { entirely free versions of the } \\
\text { game (Trackmania Nations } \\
\text { and Trackmania Nations } \\
\text { Forever) }\end{array}$ & $\begin{array}{l}\text { Development of a community } \\
\text { that is very favourableto } \\
\text { thecompany }\end{array}$ \\
\hline MySQL & $\begin{array}{l}\text { Circulation of colours and the } \\
\text { MySQL logo on the community } \\
\text { sites }\end{array}$ & $\begin{array}{l}\text { Founding of the company by } \\
\text { the community leaders }\end{array}$ & $\begin{array}{l}\text { Double license : free for } \\
\text { individuals, a charge for } \\
\text { companies for business use }\end{array}$ & $\begin{array}{l}\text { Development of a community } \\
\text { that is very favourable to the } \\
\text { company, except since the } \\
\text { takeover by Sun, then Oracle }\end{array}$ \\
\hline Propellerhead & $\begin{array}{l}\text { Circulation of colours and } \\
\text { thePropellerhead product logos } \\
\text { onthe community sites }\end{array}$ & $\begin{array}{l}\text { Company Creators and users } \\
\text { share their passion for music }\end{array}$ & $\begin{array}{l}\text { Does not use this type of } \\
\text { system }\end{array}$ & $\begin{array}{l}\text { Development of a community } \\
\text { that is very favourableto the } \\
\text { company }\end{array}$ \\
\hline Freebox & $\begin{array}{l}\text { Circulation of colours and the free } \\
\text { logo on the community sites. Loan } \\
\text { of a domain name }\end{array}$ & $\begin{array}{l}\text { Discussions during the } \\
\text { meetings with community } \\
\text { leaders }\end{array}$ & $\begin{array}{l}\text { A single low price maintained } \\
\text { for } 10 \text { years. A small amountof } \\
\text { content and servicesare } \\
\text { createdby players }\end{array}$ & $\begin{array}{l}\text { Development of a community } \\
\text { that is only slightly favourable } \\
\text { for the company }\end{array}$ \\
\hline
\end{tabular}

